\title{
ФИЛОСОФСКА АНТРОПОЛОГИЯ \\ ФІЛОСОФСЬКО-БОГОСЛОВСЬКЕ ВЧЕННЯ ПРО "ВНУТРІШНЮ ЛЮДИНУ" СВ. ЛУКИ (ВОЙНО-ЯСЕНЕЦЬКОГО)
}

\author{
О. Б. Величко \\ кандидат філософрських наук, доцент, доцент кафедри україністики \\ Національного медичного університету ім. О.О. Богомольця \\ velichko.olena@ukr.net \\ ORCID 0000-0002-8486-3836
}

DOI: https://doi.org/10.34017/1313-9703-2021-1(17)-2(18)-47-60

\begin{abstract}
Анотация
Олена Величко. Философско-богословското учение за "вътрешния човек" на Св. Лука (Войно-Ясенецки). Статията анализира философско-богословската доктрина на Св. Лука Войно-Ясенецки за човека като триединен психосоматичен организъм, който образува органично цяло във вертикалната подчиненост: тялото (целостта, която включва всички органи, системи), душата (като набор от органични и сетивни възприятия, следи от спомени, мисли, чувства, волеви актове), духът (като разумно, волево животворящо начало) във вътрешното си трансцендентално-кордоцентрично и външното телесно естество. Терминът "вътрешен човек" се определя чрез противопоставяне на "външния човек" като плътски, грешен, дезориентиран и отклонен от разума и духа. Понятието „вътрешен човек“ се разглежда като противопоставяне на греха и като някаква цялостност на съзнанието, сърцето и духа, която властва над плътта.
\end{abstract}

Ключови думи: Св. Лука (Войно-Ясенецки), "вътрешен човек”, дух, душа, кордоцентризъм, тяло

\section{Анотація}

Олена Величко. Філософсько-богословське вчення про "внутрішню людину" св. Луки (Войно-Ясенецького). В статті аналізується філософського-богословське вчення Св. Луки Войно-Ясенецького про людину як триєдиний психосоматичний організм, що складає органічне ціле у вертикалі підпорядкування: тіла (цілісніості, що включає у себе усі органи, системи) - душі (як сукупності органічних та чуттєвих сприйняттів, слідів спогадів, думок, почуттів, вольових актів) - духу (як розумного, вольового, життєдайного початку) у її внутрішньому трансцендентально-кордоцентричному і зовнішньо-тілесному єстві. Термін "внутрішня людина" визначається через протиставлення "людині зовнішній" як плотській, гріховній, дезорієнтованій і відвернутій від розуму та духу. Поняття "внутрішня людина" розглядається у праксисі протистояння гріху як деяка цілісність у її розумі, серці і духу, що панує над плоттю.

Ключові слова: св. Лука (Войно-Ясенецький), внутрішня людина, дух, душа, кордоцентризм, тіло 


\begin{abstract}
Olena Velichko. Philosophical and theological doctrine of the "inner man" of St. Luka (Voyno-Yasenetsky). The article analyzes the philosophical and theological teaching of St. Luka Voino-Yasenetsky on a person as a triune psychosomatic organism that constitutes an organic whole in the vertical of submission: the body (integrity, which includes all organs, systems) - the soul (as a combination of organic and sensory perceptions, traces of memories, thoughts, feelings, acts) - the spirit (as a smart, strong-willed, life-giving principle), in its internal transcendentally cordocentric and externally corporeal nature. The term "inner man" is defined by the opposition to "outer man" as sensual, sinful, disoriented and distracted from the reason and spirit. The concept of "inner man" is considered in the praxis of confronting sin as a certain integrity in his mind, heart, and spirit that dominates the flesh.
\end{abstract}

Key words: St. Luka (Voyno-Yasenetsky), inner man, spirit, soul, cordocentrism, body

Постановка проблеми. Підіймаючись сходами морфологічного корпусу столичного Національного медичного університету ім. О.О. Богомольця на одній з колон портику цієї споруди важко не помітити меморіальну дошку, на якій уславлено образ відомого випускника медичного факультету Київського університету св. Володимира, доктора медичних наук, науковця в царині анестезіології та гнійної хірургії, архієпископа святителя Луку (Войно-Ясенецького). Усім своїм життям, натхненною та щоденною працею він довів можливість поєднання на перший погляд сфрер не поєднуваних: науки та релігії, земного та небесного, вічного та плинного, богословських роздумів, сповнених філософськими сентенціями щодо питань, які постали перед людиною на початку XX століття.

У сучасній науковій та публіцистичній літературі постать святителя Луки як лікаря-науковця та відданого християнина - подвижника благочестя вже добре знана. Натомість, як філософ-богослов, який залишив по собі достатньо цілісне уявлення про людину як складний тілесно-душевно-духовний феномен, святитель Лука ще мало відомий. Лише на початку XXI століття з'явились друком перші публікації, присвячені життю та богословсько-філософрській спадщині Валентина Феліксовича Войно-Ясенецького (святителя, архієпископа Луки) в дослідженнях В.В. Попової (Попова, 2009), І.М.Степанової (Степанова, 2005), Л. В. Халезової (Халезова, 2007). У 2011 році на базі Інституту фрілософії імені Г.С. Сковороди Національної Академії наук України було захищено перше дисертаційне дослідження, присвячене життю та богословсько-проповідницькій діяльності архієпископа Луки в контексті його філософськорелігійних поглядів (Халезова, 2011). Проте роздуми св. Луки про людину як динамічне трискладне створіння на роздоріжжі-зустрічі науки (передовсім - в царині медицини) та християнського віровчення ще потребують додаткової аналітики. Існуючу прогалину варто заповнити. Саме тому філософсько-богословське вчення св. Луки (Войно-Ясенецького) про "внутрішню людину" і стане предметом цього дослідження.

Якою ж є головна ідея, що складає ядро християнського віровчення? Безперечно, так чи інакше, ця ідея обертається довколо питання щодо життя та смерті, а розкривається через сотеріологію ${ }^{1}$ - вчення про спасіння людини як смертної істоти, що, попри все, жадає i тягнеться до безсмертя. Різдво, служіння в ім'я життя, розп'яття і Воскресіння, як шлях-місія Нової людини - Боголюдини, стають дороговказом на шляху спасіння через віру в Ісуса Христа, віру в благодатне преображення Ним і через Нього для кожної людини як істоти мислячої, істоти творчої, вільної, що здатна не лише озираючись довкола, або підіймаючи голову до

\footnotetext{
${ }^{1}$ Від грец. $\sigma \omega \tau \eta \rho і \alpha$ - спасіння та грец. $\lambda$ о́үо - вчення, слово, як богословське вчення про спокутування та спасіння людини, що є розділом догматичного богослов’я.
} 
неба відкривати для себе нові незвідані світи, але й зосередитись на самій собі, зазирнути і відкрити світ власного "Я" - світ внутрішньої людини. Саме таку назву, "Про внутрішню людину", і дає восьмому розділу своєї книги "Дух, душа, тіло" св. Лука Войно-Ясенецький. То що ж то таке: "внутрішня людина"? Звісно, вище вживане поняття потребує пояснень. Почнемо 3 історії.

Концепт "внутрішня людина" у вітчизняному філософсько-богословському спадку. Не занурюючись в історико-філософські глибини дослідження етимології і запровадження у філософсько-богословський простір апостолом Павлом поняття «внутрішня людина», зауважимо, що термінологічно, підхоплене апологетами ранньохристиянської доби, воно було витлумачене і осмислене ще у контексті християнського праксису, у християнській книжній традиції, у творах святих отців та подвижників благочестя і було вже добре відоме і вживане.

Як відомо, вчення про три світи (макросвіт, тобто всесвіт; мікросвіт як світ малий, тобто, світ людини; "симболічний" світ як світ символів, тобто, світ Біблії) і вчення про дві натури людської (внутрішньої - як вічної, Божественної і безсмертної та зовнішньої - як пропащої, роз'їденої гріхом) щільно асоціюються з філософським спадком Григорія Савича Сковороди (1722-1794). Водночас, його земляк-полтавчанин преп. Паїсій Величковський (1722-1794) цими питаннями переймався не менше. Над ними він ррозмірковував, про це він писав в «Крины сельные или цветы прекрасные, собранные вкратце от Божественного Писания» (Величковский, 1997), навертаючись до відродження на той час вже призабутої практики "розумного роблення", "сердечної" або ж "Ісусової молитви". Утім, вчення старця Паїсія про дві натури суттєво відмінне від конклюзій Григорія Сковороди, проте напрочуд відгукується у роздумах преп. Луки. Започаткований Григорієм Савичем та преп. Паїсієм вектор роздумів на межі XIX-XX століть, знаходить своє продовження у працяХ шанованого з-поміж представників української інтелектуальної та духовної еліти єпископа Ігнатія Брянчанінова (Брянчанинов, 1989, с. 284-320), який, як мислитель та богослов, сформувався під безпосереднім впливом учня старця Паїсія Величковського ієросхимонаха Афанасія, вплив якого на школу Київської Духовної Академії був достатньо значним. Вчення про внутрішню людину старця Паїсія та Ігнатія Брянчанінова знайшли відбиток у працях як професорів Київської духовної академії (П. Д. Юркевич, В.З. Завітневич, П.П. Кудрявцев, С.С. Гогоцький, О.О. Глаголев), так і професорів Київського університету св.. Володимира (О.М. Гіляров,С.С. Гогоцький, В.В. Зенківський). Врешті-решт над цим питанням розмірковували і представники Київського кола так званої "нової релігійної свідомості", ранній етап творчого доробку яких був щільно пов'язаний з київською філософсько-богословською школою. До списку відносимо Сергія Булгакова, Миколу Бердяєва, Василя Зеньківського, Дмитра Чижевського, який, у свою чергу, у сучасному філософрсько-богословському дискурсі визнається фундатором поняття "філософії серця" (Валявко, 1998, с. 83-89).

Виклад основного матеріалу. А що ж розуміє під поняттям "внутрішня людина" сам св. Лука? Пошук відповіді на це питання варто розпочати з базового поняття: а що таке $\epsilon$ людина? Для св. Луки, як науковця-хірурга та мислителя-богослова², людина як тілесно-душевно-духовний організм потребує сутнісного їі осмислення на трьох рівнях:

- психосоматичному ${ }^{3}$, де людина об'єкт душевно-тілесний і, водночас, мислячий (як наділений свідомістю);

- трансцендентальному, де людина суб'єкт трансцендентально-духовний, наділений здатністю до самопізнання шляхом рефлексії - усвідомлення самої себе у своїх власних станах та розумових діях (як наділений самосвідомістю);

\footnotetext{
${ }^{2}$ Мав ступінь доктора богослов'я з 1959 року.

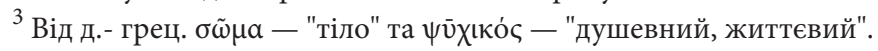


- есхатологічному4, де людина розглядається (як об'єкт і суб'єкт) у площині задуму Божого про людину як вершину творіння Всевишнього, створеного за образом та подобою Божою на шляху свого спасіння.

Варто зауважити, що роздуми св. Луки в царині антропології ґрунтуються на засадах креаціонізму ${ }^{5}$, який, в основі своїй, на його переконання, не суперечить висновкам сучасної науки. Людина, як творіння Творця усього сущого, була створена у задумі Божому за Його ж образом і за Його ж подобою таким чином, що трьохіпостасність (Отець-Син-Дух Святий) нетварної 6 природи Бога стає прообразом єднання трьохчастинної тварної7 природи людини. Як цілісний, ієрархічно структурований організм людина постає у єдності тіла, душі і духа. Отже, св. Лука є представником трихотомістичного погляду на людину.

Звідси виникає питання, яким задається і сам св. Лука, розпочинаючи шостий розділ своєї книги: "То яке ж співвідношення між духом, душею і тілом? " (Лука (Войно-Ясенецкий), 2009 , с. 73). Пошук відповіді здійснюється через осмислення особливостей взаємозв'язку цих трьох складових (тіла, душі та духу) на трьох взаємопов'язаних і взаємозалежних рівнях: тілесно-душевному (психосоматичному), душевно-духовному та духовно-тілесному. Аналіз кожного з них розпочнемо саме з психосоматики.

Тіло. Під поняттям "людське тіло" в сучасній системі знань вже усталено розуміють фрізичну структуру людини, утворену клітинами різних типів в єдиний цілісний організм, які, у свою чергу, організуються в тканини, а останні - в органи, системи. Натомість, у творах Отців Церкви (передовсім - у аскетичній літературі і традиції) поняття "тіло", як матеріально-зовнішня оболонка людини, включало в себе дещо ширший зміст. Так, арх. Іаннуарій (Івлев), аналізуючи основні антропологічні поняття у посланнях ап. Павла, зауважує: "Ми не будемо неправі, якщо подумки станемо замінювати слово тіло в його посланнях словами людина, індивідуум, особистими займенниками: моє тіло = я, його тіло = він" (Іаннуарій (Івлев), 2001, с.15). Для розуміння змісту вище зазначеного важливо відзначити, принаймні, два аспекти: "...Павло не мислить людину без тіла" і апостол "..ніколи не використовує слово тіло у значенні трупу" (Іаннуарій (Івлев), 2001, с.15). Тому, у якості висновку слід зазначити, що вже у посланнях ап.. Павла "...не слід розуміти тіло як форму, заповнену різною матерією (плотською або духовною). Тіло людини - у її цілісності" (Іаннуарій (Івлев), 2001, с.15). Тобто, тіло - це і є явлення людини у її цілісності.

Водночас, як відзначають дослідники цього питання, вже у тексті послань ап. Павла

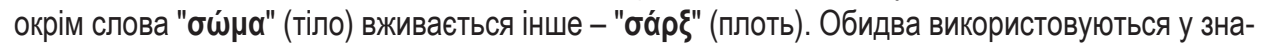
ченні фізичної оболонки людини. Проте, як писав арх. Кипріян (Керн), лише "...для поверхневого погляду різниця майже непомітна, але для того, хто знає дух мови, вона доволі відчутна". І додає далі: "Справжній сенс цих виразів у ап. Павла все ж таки не завжди залишається зрозумілим" (Кипріян (Керн), 1950, с. 75). І у якому контексті? Мабуть, найбільший резонанс у цьому випадку викликає тлумачення у посланні ап. Павла такого "тьмавого місця": "Тіло ж не для розпусти, але для Господа, і Господь для тіла" (6:13). Так, арх. Іаннуарій такого типу непорозуміння пов'язує з історичним зміщенням смислів, бо ж тлумачі текстів ап. Павла той

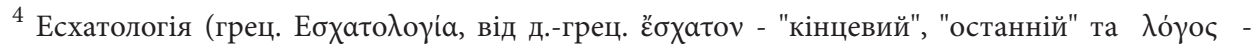
"слово", "знання") - система релігійних поглядів і переконань про долю Всесвіту і людини відносно його завершеності як то: кінця світу, загробного життя, переходу в якісно новий стан існування.

5 Креаціонізм - доктрина, що грунтується на визнанні і вірі в те, що людина і всесвіт (все живе і неживе на Землі) створені надприродною (нетварною) силою у розумному задумі Бога-Творця.

${ }^{6}$ Вживається у значенні як ніким не створеної сутності.

${ }^{7}$ Вживається у значенні як створеної Творцем усього сущого.
} 
зміст, який вкладав апостол у поняття "тіло", вже "не розуміли павліністично"8, а отже - у його цілісності, і від того сприймали виключно у значенні фрізично-плотського. (Іаннуарій (Івлев), 2001, с.16). При цьому показово, що: "Термін душа (чuхи́) у апостола Павла зустрічається рідко; разом зі словом "тіло" - тільки в 1 Фес 5:23. Павло ніде не протиставляє душу тілу в сенсі елліністичного дуалізму» (Іаннуарій (Івлев), 2001, с.16). Саме ця ключова деталь робить зрозумілим те, яким чином, врешті-решт, за поняттям «тіло» закріплюється слово "плоть" у значенні недосконалого буття як підвладного тлінню, як буття недосконалого, або ж позбавленого повноти. А вже наслідковим ефектом слово "плоть" (плотський) стає синонімічним слову "тварина" (тваринність) і, як приклад, у "Аналітичному Словнику Ісихастської Антропології" С. С. Хоружого концептуально стає висхідним моментом "специфічно православного дискурсу, дискурсу вершення і обожненням (Хоружий, 1995, с.44).

Отже, термін "тіло" у ап. Павла використовується у значенні не просто фрізичної структури-оболонки людини, але й у значенні тієї цілісності як ціннісної цілі людини, яка, хоча й ушкоджена гріхом, але не позбавлена надії на зцілення як відновлення, як повернення до тієї чистоти, яку вона втратила у своєму гріхопадінні. Саме у такому контексті і мислить тіло св. Лука, який його синонімом також вживає слово "плоть". Для нього очевидно, що людське тіло як дещо фізичне і внутрішній світ людини щільно взаємопов'язані. Про характер такого взаємозв'язку, такої взаємозалежності психічного стану людини від нормальних або патологічних функцій її органів та систем, як то: головного мозку, функцій організму внутрішньої секреції, гормональної системи - святитель писав так: "Усе, що відбувається в організмі, і сама анатомічна побудова його, накладає глибокий відбиток на психіку. Різноманітним конструкціям тіла відповідають ті або інші форми характеру, а характер - одне з найважливіших проявів душі та духу" (Лука (Войно-Ясенецкий), 2009, с. 73). Отже, людське тіло певною мірою виявляє і на тілі відбивається душевно-духовний стан людини. Святитель вважає: якщо не викликає сумнівів теза про те, що "...соматичні процеси значною мірою визначають перебіг психічних процесів, то настільки ж...необхідно визнати і психічний вплив на всі соматичні процеси в організмі" (Лука (Войно-Ясенецкий), 2009, с.74). Як відомо, однією з систем людського організму є центральна нервова система. Центральна нервова система - це певна система органів, побудованих з нервових клітин. Вона координує функціонування та взаємозв'язок всіх інших систем та органів людського організму у єдине ціле. Шість частин центральної нервової системи з семи, як відомо, об'єднані під назвою "головний мозок". То ж яку функцію в організмі людини, як істоти мислячої, мозок виконує?

Мозок. Вдаючись до полеміки з вульгарно-матеріалістичним, як домінуючим в радянському суспільстві підходом, за яким "усі психічні акти вважалися функцією мозку" (Лука (Войно-Ясенецкий), 2009, с..73), святитель зауважив, що у відповідності до останніх наукових досліджень в царині фрізіології є: "...абсолютно очевидним, що не лише головний мозок, але й ганглії комах, спинний мозок і симпатична нервова система хребетних слугує органом волі" (Лука (Войно-Ясенецкий), 2009, с. 29). Зважаючи на особливості структури кори півкуль головного мозку, яка складається з величезної кількості аналізаторів, св.. Лука звертає увагу на ще одну корінну помилку, якої припускається вульгарно-матеріалістичний тип мислення: "... мозкова кора аналізує не почуття, а відчуття" (Лука (Войно-Ясенецкий), 2009, с. 35). Як відомо в людському мозку розрізняють не лише рухові, сенсорні, але й вазомоторні, дихальні, теплові центри. Проте донині, як зауважує святитель, "...нікому не відомі центри радості та печалі, гніву та страху, естетичного та релігійного почуття" (Лука (Войно-Ясенецкий), 2009, с. 25). Звідси й випливає висновок: якщо "...не робити відмінностей між відчуттями та почуттями значить впадати у саму глибоку психологічну помилку" (Лука (Войно-Ясенецкий), 2009, с. 25).

Послуговуючись не лише науковими висновками фізіолога Павлова, але філософ-

\footnotetext{
${ }^{8}$ Від лат. Рaul "Павло", англ. Pauline Christianity "павлове християнство".
} 
ськими розвідками Артура Шопенгауера та Анрі Бергсона, св. Лука наполягає на тому, що: "різниця між спинним мозком, який ресрлекторно реагує на імпульси, що отримує, і головним мозком - лише у складності, а не у характері функцій. У головному мозку лише реєструється сприйняття, яке приходить зовні, і вибирається належний спосіб відповідної реакції" (Лука (Войно-Ясенецкий), 2009, с. 30). Цитуючи влучний вислів Анрі Бергсона, св. Лука порівнює мозок з "центральною телефонною станцією" (Лука (Войно-Ясенецкий), 2009, с. 30). Тобто, мозок людини - це лише своєрідний комутатор. Звідси робиться висновок про те, що: "Мозок не $€$ органом думки, почуттів, свідомості, але він $€$ те, що приковує свідомість ${ }^{9}$, почуття, думки до дійсного життя, змушує їх прислухатися до дійсних потреб і робить їх здатними до корисної дії" (Лука (Войно-Ясенецкий), 2009, с. 30-31). Апелюючи до висновків І. П. Павлова, св. Лука стверджує, що саме центральна нервова система людського організму "...головує над усіма соматичними процесами, визначає й спрямовує роботу усіх органів, їхнє зростання і трофічний стан, могутньо впливаючи на перебіг фізіологічних процесів" (Лука (Войно-Ясенецкий), 2009, с. 74). Однак, зводити пізнавальні процеси виключно до соматико-фізіологічних у науковця немає підстав, бо ж на переконання св. Луки людина має не одну, а дві взаємодіючі пізнавальні системи: раціональну та інтуїтивно-містичну ${ }^{10}$. А від того, мова йде про існування особливого органу вищого пізнання та почуття людини і цим органом, на переконання св. Луки, є серце. Йому він присвячує другий розділ книги.

Серце. Отже, в організмі людини серце виконує подвійну функцію: воно є не лише "центральним мотором кровообігу" (Лука (Войно-Ясенецкий), 2009, с. 15), але й органом почуттів, органом вищого пізнання - спілкування людини з Богом-Творцем. Але ж, які на користь цього твердження будуть аргументи? Аргументація св. Луки має не лише теологічний, філософрсько-богословський характер, але й опирається на аналітику особливостей фізіології людини.

Як ревний християнин та богослов св. Лука посилається на Святе Письмо, згідно якому саме серце "мислить, розмірковує, пізнає" (Лука (Войно-Ясенецкий), 2009, с. 22-23). "Коли мудрість увійде у серце твоє, і знання будуть приємні душі твоїй. Тоді розсудливість буде оберігати тебе, розум буде охороняти тебе" - читаємо у Притчах Соломонових (Притч.2, 10-11). Цитування подвижників благочестя, які практикою творіння розумно-сердечної молитви ("розумного діяння") ${ }^{11}$ набирались духовного досвіду (св. Єфррем Сирин, св. Макар Єгипетський та ін. $з$ текстів Добротолюбія або ж Філокалія $\left.{ }^{12}\right)$, стають іще одним аргументом для підтвердження думки про те, що: "серце керує усіма органами, і коли благодать займе усі відділення серця, то панує над усіма помислами і членами, бо ж там ум і усі помисли душевні" (Лука (Войно-Ясенецкий), 2009, с. 16). Схожі судження святитель знаходить і у роздумах Б. Паска-

\footnotetext{
${ }^{9}$ Цікавими видаються й паралелі у порівнянні роздумів св. Луки з базовими положеннями концепції сучасного нейробіолога К. В. Анохіна. Концепція відома під назвою "когнітому" гіпермережевої моделі мозку (Анохин, 2013, с. 83-89).

${ }^{10}$ Нові методи тривимірного картування роботи головного мозку та дослідження у сфері когнітивної психології переконують нас у тому, що не існує єдиного пізнавального процесу. У когнітивній науці сучасні науковці виділяють три системи уваги, кілька систем сприйняття, від чотирьох до п'яти систем пам'яті, дві системи мислення (раціональна та інтуїтивна) та дві системи уявлення (репродуктивного та творчого).

11 "Розумине діяння", або ж "Умное делание" -рос.- (від поняття "ум" - у якості трансцендентально-духовного центру людської істоти; "делание" - у значенні роботи-творіння Іісусової молитви) - практика творіння неперервної так званої сердечної або ж Іісусової молитви, яку аскет безперервно повторював протягом всього свого життя. "Умное делание" є однією з умов очищення душі аскета від гріха задля сходження на нього Благодаті і, від того, своєрідним знаряддям на шляху до синергії власних інтенцій-енергій та нетварної енергії Божої - Благодаті. 12 Збірки духовних творів святих отців IV-XV століть, яка слов'янською була перекладена саме прп. Паїсієм Величковським.
} 
ля, і у роздумах А. Бергсона. Обмеженість пізнавальних можливостей раціоналістичного або, як називав Б. Паскаль, "геометричного розуму" має бути доповнене мисленням інтуїтивним, бо ж саме "...серце, а не розум відчуває Бога" (Лука (Войно-Ясенецкий), 2009, с. 28). Отже, ту "пізнавальну здатність", яку Б. Паскаль визначає як "почуття тонкощів", а А. Бергсон називає "інтуїцією", святитель Лука визнає "вищим почуттям" як почуттям, яке виходить з серця. (Лука (Войно-Ясенецкий), 2009, с. 36).

Навертаючись до Святого Письма, св. Лука серце людини, як "...орган бажань та джерело волі, добрих та злих справ" (Лука (Войно-Ясенецкий), 2009, с. 22), уподібнює посудині, бо ж: "Серце нерозумного схоже на розбитий жбан і не утримує у собі ніякого знання" (Лука (Войно-Ясенецкий), 2009, с. 24). Особливу увагу святителя привертає Євангелічний сюжет, у якому два учні-апостоли йшли дорогою з Єрусалиму в Еммаус і жваво обговорювали воскресіння Ісуса Христа та, при тому, у своєму супутнику не одразу впізнали воскреслого Вчителя. А коли повернулись до Єрусалиму та сповістили про цю подію іншим апостолам, Ісус Христос з'явився поміж ними. Одначе апостоли не мали віри побаченому і убоялися його як духа. Про цю подію в Євангелії від апостола Луки виразно сповіщають слова-звернення Ісуса Христа до своїх учнів: "Для чого такі думки входять в серця ваші? " (Лук. 24, 38). Важливо, що над цим питанням св. Лука Войно-Ясенецький розмірковує не лише як богослов, але й як мислительнауковець. Шукаючи доказів наукового підтвердження богословським істинам, і відштовхуючись від питання ключового - Біблійного він формулює питання похідні: "Як ці думки входять в серця ваші? Звідки входять? Якщо входять в серце, то значить не народжуються в ньому?" (Лука (Войно-Ясенецкий), 2009, с. 25). I, нарешті: що на рахунок вище перерахованих питань можуть відповісти сучасні фрізіологія та фізика?

Як лікар хірург та анестезіолог св. Лука відмічає, що серце тісно пов'язане з мозком. Добре відомо, що "...іннервація серця дивовижно багата та складна. Воно все сплетене сіткою волокон симпатичної нервової системи і через неї найтіснішим чином зв'язане з головним та спинним мозком" (Лука (Войно-Ясенецкий), 2009, с.14). Завдяки п'яти органам почуттів (як то: зорових, слухових, нюхових, тактильних та смакових ${ }^{13}$ ) через рецептори головний мозок людини отримує необхідну інформацію і, таким чином, формує сприйняття людиною як навколишнього світу - макросвіту, так і світу внутрішнього - людиною самої себе. Проте, "... крім звичних подразнень, адекватних нашим органам відчуттів", на переконання св. Луки, ".. наш мозок і серце можуть сприймати значно більш важливі подразнення, які виходять із мозку та серця інших людей, тварин і усієї навколишньої нас природи і, що найважливіше за все, з невідомого нам трансцендентального світу" (Лука (Войно-Ясенецкий), 2009, с.40). Мова йде про нове, за св. Лукою "шосте відчуття", яке надає можливість людині сприймати чисто духовну енергію", яку він ще називає "...первинною і першо-родовою усіх фізичних форм енергії, а через них і самої матерії" (Лука (Войно-Ясенецкий), 2009, с.11).

Чому матерії? Бо ж посилаючись на вагомі досягнення сучасної фізики - корпускулярної теорії електрики: "...енергія не може зникати або утворюватись з нічого. Вона тільки може змінювати свою матеріальну оболонку, кількісно залишаючись тією ж самою" (Лука (ВойноЯсенецкий), 2009, с. 7). Прикладом такого перетворення матерії в енергію він називає процес анігіляції ${ }^{14}$, коли при низьких енергіях електрон-позитронної пари відбувається перетвореннявипромінювання двох або трьох фотонів. Відповідно, зворотний процес отримав назву "матеріалізації", бо ж: "...енергія володіє масою, а маса належить деякій реальності - матерії" (Лука (Войно-Ясенецкий), 2009, с.9). Ось чому поряд з інфрачервоним та катодним випромінюванням, радіохвилями, радіоактивністю та внутрішньоатомною енергією св.. Лука називає

\footnotetext{
13 св. Лука не згадує лише кінетичні - почуття рівноваги та розміщення тіла у просторі.

${ }^{14}$ Від лат. Annihilatio - знищення, відміна.
} 
світло також "...однією з форм електромагнітної енергії" (Лука (Войно-Ясенецкий), 2009, с.7) та символом "енергії духовної", здатність до сприйняття якої і має саме людське серце. То ж які функціональні характеристики та можливості людське серце має?

- Серце - це орган відчуттів та сприйняття духовної взаємодії, орган спілкування, зв'язку; тому серце - це і "центр нашого духовного життя та Богопізнання" (Лука (Войно-Ясенецкий), 2009, с.20).

- Серце - це осереддя людської волі, "орган бажання, джерело волі, добрих та злих помислів" (Лука (Войно-Ясенецкий), 2009, с.22).

- Серце - це орган пізнання людини, серце мислить, розмірковує, пізнає (Лука (ВойноЯсенецкий), 2009, с.23) і є "сідалищем" (місцем, вмістилищем) думки15.

Думка. То що ж таке думка? Процес обробки інформації в мозку людини? Шукаючи відповідь на ці питання, св. Лука посилається на дослідження відомих науковців у царині метапсихології 16 і приходить до висновку про те, що: думка - це також енергія, але енергія особлива. Оскільки думка має як психічні, так і фізичні властивості, то таку енергію він називає "психофрізичною". Так, народжуючись в мозку людини, психофрізична енергія "...поширюється до кінцівок тіла. Вона важко передається повітрям, розходиться по металевим провідникам" (Лука (Войно-Ясенецкий), 2009, с.39) і не є типовою для переважної більшості людей. Проте, для сенситивного ${ }^{17}$ суб'єкта саме вона забезпечує появу такого феномену як криптостезія ${ }^{18} \mathrm{y}$ тих ситуаціях, коли ми дивуємося як "...таємничим чином думка однієї людини сповіщається іншим людям" (Лука (Войно-Ясенецкий), 2009, с.43). Особливо цікавим, на переконання святителя, видається феномен криптостезії не стільки у відношенні до минулих подій, скільки у проекції до майбутнього, тобто, передбачення. Щоправда, шукати простих пояснень такому феномену, який матеріалісти зводять до простої обумовленості "...рухом мозкових частинок, що хвилеподібно передаються у просторі" (Лука (Войно-Ясенецкий), 2009, с. 106), св. Лука вважає недоречним, оскільки наведені у книзі приклади спілкування з померлими, за вже наявної відсутності у небіжчиків здатного до функціонування мозку, ставить цю гіпотезу під сумнів.

Отже, думка - це енергія і енергія тварна (тлінного світу) ${ }^{19}$, яка відходить від людини і випромінюється назовні. Водночас, поряд з енергією тварною є й така енергія, якою пронизаний увесь всесвіт. Авторитет лауреата Нобелівської премії з фізіології та медицини за 1913 рік, відомого французького фізіолога Шарля Робера Ріше надає підстави св. Луці стверджувати те, що: "У всесвіті існують Коливання (сили), які збуджують нашу чуттєвість і обумовлюють достовірне пізнання дійсності, якого наші нормальні почуття не можуть надати" (Лука (ВойноЯсенецкий), 2009, с.39). Про існування у природі таких вібрацій-енергій, які пронизують увесь світ, у своїй книзі св. Лука згадує неодноразово. Джерелом таких духовних вібрацій-енергій св. Лука називає Дух Божий, якого у тексті книги він називає ще "джерелом життя". Збуджу-

\footnotetext{
15 У Біблійний енциклопедії слово "сідалище" вживається у значенні престолу як священного місця, як місця для сидіння. Звідси, як похідні, слова: "сідло", "сідниці".

${ }^{16}$ Метапсихологія (грец. "meta" - після, або за, "psiche" - душа i "logos" - вчення, слова, наука) - це вчення про душу, а дослівний переклад - "за психологією".

17 Сенситивний суб’єкт (лат. sensus - почуття, відчуття) - особливість людини, що характеризує його спроможність відчувати, розрізняти та реагувати на зовнішні подразники. 18 Термін запропонований французьким фізіологом Шарлем Робером Ріше у значенні прозорливості, ясновидіння.

${ }^{19}$ Поняття "Тварний світ" тут вживається у значенні світу створеного Творцем. Згідно Святому Письму Господь, як Творець усього сущого, створив увесь світ і, у тому числі, людину. Тому, той створений Господом світ, отримав назву "тварного" і відзначається такими характеристиками: матеріальність, плинність, змінність і від того - він має початок і кінець. Сам світ Божественний, як ніким і ніколи не створений, позначається терміном "нетварний".
} 
ючи нашу чуттєвість, ці таємничі вібрації-енергії мають здатність не лише приводити "в рух людський інтелект", але й відкривати "...йому факти, повідомити про які безсилі його почуття" (Лука (Войно-Ясенецкий), 2009, с. 105). То що ж таке дух?

Дух. 3-поміж науковців немає одностайної думки та одностайного тлумачення цього концепту. У літературі понині не вщухають дебати навіть на рахунок розуміння цього питання апостолом Павлом, на якого посилається у своїх роздумах св. Лука. I підстави для цього є, бо, як писав арх. Кипріян (Керн): "Самий, можливо, незрозумілий термін антропології ап. Павла

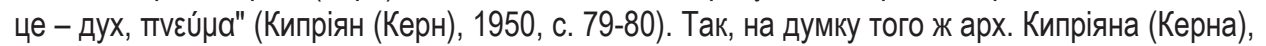
для ап. Павла: "Наш дух є вівтар, на якому спочиває Дух Божий" і тому під поняттям "дух" розуміється "...особливий стан внутрішнього життя людини, а не частина його внутрішньої структури" (Кипріян (Керн), 1950, с. 82-83). Натомість, арх. Іаннуарій (Івлев), акцентуючи увагу на достатньо часто уживаній ап. Павлом змістовній тотожності понять "дух" та "душа", у трихотомії дух-душа-тіло поняття "дух" розглядає, передовім, крізь призму гносеології і від того пов'язує його з розумом. По це він пише так: "Дух" не є якийсь вищий в порівнянні з "тілом" або "душею" принцип. "Дух" є, як і "тіло" і "душа", - людина. Але якщо "тіло" є людина в його об'єктивності, то "дух" означає людину як суб'єкта, переважно як суб'єкта пізнання. I в цьому

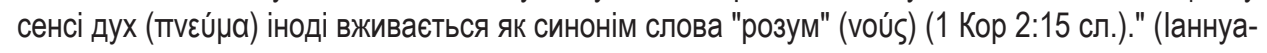
рій (Івлев), 2001, с.17).

Для св. Луки також очевидно, що дух та розум взаємопов'язані: "Розум, звісно, не дух, а лише виявлення духу. Розум відноситься до духу як частина до цілого" (Лука (Войно-Ясенецкий), 2009, с. 37). Дещо нижче, у сьомому розділі своєї книги, святитель більш детально описує цей зв'язок: "... Життя духу неподільно і найтіснішим чином пов'язане з усією нервовопсихічною діяльністю. У ньому (дусі) відбиваються усі наші думки, почуття, вольові акти - усе те, що відбувається у нашій феноменальній свідомості. Це дещо інше, ніж ті сліди і відбитки у нервових клітинах, якими фрізіологи та психологи пояснюють пам'ять" (Лука (Войно-Ясенецкий), 2009, с. 100). Таким чином, поняття "дух" тут вживається у значенні одухотвореності людини як людини розумної, відкритої до осягнення Істини не розсудком, а розумом - як вищою формою абстрактно-теоретичного осягнення дійсності, осмисленого в традиціях німецької класичної фрілософії, вже починаючи від Іммануїла Канта, на авторитет якого св. Лука посилається неодноразово (Лука (Войно-Ясенецкий), 2009, с. 111-113). Проте, на переконання св. Луки людський "розум - лише частина духу, а не увесь дух" (Лука (Войно-Ясенецкий), 2009, с. 67). Саме тому "...дух не безумовно пов'язаний з душею і тілом" (Лука (Войно-Ясенецкий), 2009, с. 73). Відкидаючи упередження на рахунок ймовірних звинувачень у прихильності св. Луки до гілозоїзму, варто зауважити, що для автора книги "Дух, душа, тіло" поняття "дух людський" не є тотожне уже вживаному у Святому Письмі поняттю, відомому як "Дух Божий". Водночас, наполягаючи на тісному між ними взаємозв'язку, св. Лука характеризує його так: "дух людський має початок у Дусі Божому" (Лука (Войно-Ясенецкий), 2009, с. 70). Таким чином, святитель чітко вирізняє дух людський, Дух Божий як третю іпостась Святої Трійці і ту енергію, що відходить від Духа Святого, яка визначається ним як енергія нетварна, енергія життєдайної любові, що є "...первинною формою, родоначальницею і джерелом усіх форм фізичної енергії" (Лука (Войно-Ясенецкий), 2009, с. 44). Саме вона і є тією енергією, яка пронизує увесь світ, бо ж Дух "дихає де хоче" і "Дух животворить" (Ін. 6, 63). Отже, логіка святителя у цьому питанні така: дух людський має початок в Дусі Божому, але дух людський Духом Божим не є, бо ж Дух є Бог і Бог є любов, і "вилив Духу Його є вилив любові на все існуюче" (Лука (Войно-Ясенецкий), 2009, с. 44). Але що то таке "все існуюче", яке місце займає людина у ньому і який між ними взаємозв'язок?

На переконання св. Луки вічної матерії не існує, та й сама матерія - це "...лише енергія у ії різноманітних формах" (Лука (Войно-Ясенецкий), 2009, с. 44) і її явлений конденсат. 
А поскільки всесвітом керує один всезагальний закон, то чітку межу між живим і мертвим важко віднайти: "Немає чітких кордонів між неорганічною і органічною природою. Така точка зору сучасної науки" (Лука (Войно-Ясенецкий), 2009, с. 45). Логіка роздумів святителя далі наступна: формою існування природи є рух, бо ж рух складає сутність матерії, рушієм якої $€$ дух життя або ж енергія духу. Св. Лука про це писав так: "Духовна енергія, що витікає від Духу Божого, енергія любові рухає усією природою і усе животворить. Вона є джерелом життя і немає нічого мертвого. ...Духовною енергією просякнута вся неорганічна природа, увесь всесвіт" (Лука (Войно-Ясенецкий), 2009, с. 47).

Проте, залежно від складності організації матерії визначаються її особливості та потенціал. Погоджуючись з думкою Едуарда Гартмана про володіння рослинами несвідомого уявлення та несвідомої волі (Лука (Войно-Ясенецкий), 2009, с. 58) та посилаючись на роздуми з цього предмету Антонія Великого, св. Лука виділяє чотири типи живих істот і порівнює їх між собою. Якщо людина має розум, душу і дихання, тварина має дихання та душу, то у рослин немає ні розуму (людина), ні душі (тварина), ані ангельського безсмертя. Є лише життя - життєва енергія. Отже: "... лише у вищих формах розвитку (творіння) ця енергія досягає значення вільного, само-усвідомлюваного духу" (Лука (Войно-Ясенецкий), 2009, с. 47). Який же зміст вкладає у поняття "самоусвідомлюваний дух" святитель Лука?

Свідомість і самосвідомість. Пошук відповіді на це питання розпочнемо з визначення загального поняття: що є свідомість для св. Луки? Авторитет відомого фізіолога І. П. Павлова надає підстави, посилаючись на його висновки, запропонувати визначення, за яким під свідомістю розуміється "...нервова діяльність відповідної ділянки великих півкуль, яка у цей момент за цих обставин відзначається відомою оптимальною ...збудливістю...", де "...3 легкістю формуються нові умовні рефлекси і успішно виробляються диференціювання" (Лука (Войно-Ясенецкий), 2009, с. 60). Проте, ділянка мозку людини з оптимальною збудливістю складає лише його невелику частку. Натомість, діяльність усіх інших відділів він відносить до діяльності неусвідомлюваної або ж автоматичної. Передбачаючи ймовірний експеримент з вивчення активності роботи мозку, святитель писав про це так: "якби можливо було бачити крізь черепну коробку, і якби місце великих півкуль з підвищеною збудливістю світилося, то ми б побачили б на свідомо думаючій людині, як по її великим півкулям пересувається постійно змінювана за формою і величиною, примхливо неправильних контурів світла пляма, оточена...більш або менш значною тінню" (Лука (Войно-Ясенецкий), 2009, с. 61).

Отже, оскільки попередньо запропоноване І. П. Павловим визначення не у повній мірі розкриває зміст розуміння свідомості, то для розуміння справи св. Лука пропонує розділити свідомість на акти (дії, вчинки), стани (від спокійних, раціональних, вольових до бурхливих, емоційних, неусвідомлюваних) та виділити його обсяг. Акти свідомості викликаються різними чинниками і таких св. Лука виділяє п'ять: за допомогою органів почуття людини; органічними відчуттями людського тіла; сприйняттями, які походять від нашого трансцендентального єства; сприйняттями від нашого духовного світу та безпосередніми впливами нашого духу (Лука (Войно-Ясенецкий), 2009, с. 62). Комплекс актів свідомості, які відбуваються одночасно і знаходяться у постійній зміні, визначають стан свідомості людини, а глибина, різноманітність та пишнота визначають його обсяг. I що важливо, акти свідомості не є ізольованими, бо ж: "думка завжди супроводжується почуттям, почуття і воля думкою, а почуття - вольовими рухами" (Лука (Войно-Ясенецкий), 2009, с. 62). Так формується самосвідомість. Св. Лука про це писав так: "Усвідомлення своєї особистості складається у людини з органічних відчуттів, які вона отримує від свого тіла, від сприймань, які вона отримує органами почуття, з усієї сукупності спогадів, з розуміння свого духу, характеру, настроїв" (Лука (Войно-Ясенецкий), 2009, с. 67). Проте, у цьому переліку елементів бракує суб'єкта. На переконання святителя таким суб'єктом самосвідомості може бути лише дух: "Не розум, як зазавичай вважають, а дух. Бо 
ж розум - лише частина духу, а не весь дух" (Лука (Войно-Ясенецкий), 2009, с. 67). Ось іще одна цитата: "Глибинну сутність єства нашого пізнаємо ми не розумом, а духом. Самосвідомість $€$ функція духу, а не розуму" (Лука (Войно-Ясенецкий), 2009, с. 68). Але, яке ж місце у цій системі займає душа і чим вона $є$ ?

Душа. Св. Лука пропонує таке визначення: "Душу можна розуміти як сукупність органічних та чуттєвих сприйняттів, слідів спогадів, думок, почуттів, вольових актів, але без обов'язкової участі у цьому комплексі вищих проявів духу, не властивих тваринам та деякім людям" (Лука (Войно-Ясенецкий), 2009, с. 63). Отже, душа та дух "нероздільно поєднані за життя людини у єдину сутність", цілісність якої визначається мірою тяжіння людської души до духу (Лука (Войно-Ясенецкий), 2009, с. 63). Людина, як єдиний психосоматичний організм, $є$ доволі динамічною істотою. Кожна людина має свій рівень духовності як глибини взаємопроникнення духа та душі в єдину сутність, і цей рівень не є остаточно визначеним та стабільним. У одних він достатньо високий, і тому таку душу називають "духовною", а у інших, навпаки, достатньо низький, і за таких обставин людська душа наближається до тваринного рівня. Очищення від гріху, який нерідко в аскетичній літературі порівнюють з кіптявою на людській душі, що з плином часу причиняє шляхи до відкритості душі людській Благодаті Божої як нетварної енергії, перетворюється у щоденну невтомну працю. 3 дитинства дух наповнює людське єство але з віком самою людиною розточується, бо ж саме Дух надає сили і Дух оформляє красу: "Дух чистий і сумирний творить собі повне краси та ніжності житло" (Лука (Войно-Ясенецкий), 2009, с. 49).

Отже, в трьохчастинній структурі феномену людини, яка перетворюється на єдине органічне ціле у вертикалі підпорядкування тіла (цілісність, що включає у себе усі органи, системи) - душі (як сукупності органічних та чуттєвих сприйняттів, слідів спогадів, думок, почуттів, вольових актів), а душа - духу (як розумному, вольовому життєдайному початку) кристалізується і, водночас, ховається щось потаємне, глибинне і непізнаване, яке утримує усю цю вертикаль і яка первинно, від зачаття, тягнеться у час і простір, щоб з нього ж вислизнути у вічність. Мова йде про внутрішню людину.

Внутрішня людина. Почнемо з терміну. Як відомо, словосполучення "внутрішня людина" уперше упроваджується в християнський текст альтернативою "зовнішній людині" саме ап. Павлом (2 Kop.IV, 16), авторитет якого для св. Луки був вельми значущим. В енциклопедичних розвідках, вже традиційно, під "зовнішньою людиною" розуміється її тіло (плоть), а під "внутрішньою людиною" - ії розум, серце, совість і дух. Але не все так однозначно. Наприклад, арх. Киприян (Керн) у своїх висновках згадує "Послання до римлян" ап.. Павла, зокрема: "... Зважаючи на те, що у Рим. VII, 22-23 "розум" і "внутрішня людина" стоять один замість іншого, то ж можна, здавалося б, їх вважати синонімами" (арх. Киприян (Керн), 1950, с.83). Для нього дихотомія людини зовнішньої і внутрішньої відповідає дихотомії людини прадавньої, гріховної, з недосконалим розумом, роз'їденим гріхом, як "людини тління і пожадливості" і людини нової у значенні оновленої у боротьбі з тим гріхом (гріховними помислами) - "нового створіння Божого, служителя святості і істини" (арх. Киприян (Керн), 1950, с.83). Як слушно відзначає П. В. Коряков, у богослов"ї апостола Павла ідея духовного вершення людини єднає в одне ціле (а не протиукладає) виховання тіла з вихованням душі. Так: "Тіло, як атрибут давньої людини, розпинається у апостола на хресті Христовому укупі зі спокусливими похотями та справами" (Коряков, 2014, с.653).

На дихотомії зовнішньої як людини прадавньої і людини внутрішньої як людини нової і вибудовується вчення св. Луки (Лука (Войно-Ясенецкий), 2009, с. 113). І вибудовується воно таким чином, що внутрішня людина протиукладається зовнішній як недосконалій, гріховній і така недосконалість виявляє себе саме тоді, коли устрій взаємозалежності усіх трьох складових структури людського Я, де дух панує над душею, а душа - над тілом, кардинально 
змінюється. Так, під тиском гріху, як відступу від Істини, Абсолюту і Краси, формується обернена взаємозалежність, де дух підпорядковується душі, а душа підпорядкована тілу і тим пристрастям, що продукуються тілом. Для святителя Луки очевидною є здатність людського духу, що "є диханням Духу Божого" (Лука (Войно-Ясенецкий), 2009, с. 115), до сприйняття у природі існуючих як надприродних "...невідомих "вібрацій", які приводять в рух людський інтелект, і які відкривають йому факти, повідомити про які безсилі його почуття". Для нього зрозумілим є і те, що: "Чим вище духовність людини, тим яскравіше виражається ця здатність вищого пізнання" (Лука (Войно-Ясенецкий), 2009, с. 109). І у цій тезі приховується відповідь на запитання: "Чому для св. Луки "...розумом осягнена людина Канта, як те, що він називав "річчю у собі", "трансцендентальне я" Шарля Дю-Преля та апостола Павла "внутрішня людина" - є сутнісно тотожними"? (Лука (Войно-Ясенецкий), 2009, с. 113). На переконання святителя, кожна людина, як істота динамічна і відкрита до змін, несе у собі потенціал можливостей оновлення притуплених під дією гріха трансцендентальних здібностей людського духу. Щоправда, за умови: "...для виявлення над-свідомості необхідно, щоб згасла або, у меншій мірі, значно ослабла нормальна, феноменальна свідомість" (Лука (Войно-Ясенецкий), 2009, с. 109). Той шлях, на якому розкриваються трансцендентальні здібності людського духу, прокладається через серце, про яке св. Лука писав так: "Серце є орган вищого пізнання, орган спілкування з Богом і усім трансцендентним світом. I воно ніколи не спить. " (Лука (Войно-Ясенецкий), 2009, с. 108).

Висновки. Філософського-богословські роздуми св. Луки Войно-Ясенецького про людину як триєдиний психосоматичний організм (дух, душа і тіло) та її внутрішнє трансцендентально-кордоцентричне і зовнішньо-тілесне єство складають єдину, достатньо цілісну систему, що ґрунтується не лише на Святому Письмі і вченні святих отців - подвижників благочестя, але й на філософському та науковому здобутку поколінь вчених, для частини яких, пошуки Істини склали зміст їхнього життя. Власне, як і для автора роботи "Дух, душа, тіло", аналітика тексту якого породила нові питання і смисли. Очевидно, що для Святителя вчення про внутрішню людину як образу святості і вічності, очищеної від кіптяви гріху на шляху спасіння, перетворюється на наріжний камінь його сотеріології, яка в реаліях сучасного постінформаційного суспільства, спрямованого на пошук цілісності і цілі духовно-практичної діяльності людини (проблема праксису ${ }^{20}$ ) набувають нової значущості і актуальності.

\section{Література та посилання}

Анохин Константин, (2013), "Коды вавилонской библиотеки мозга", В мире науки. Спецвыпуск, c. 83-89.

Валявко І. (1998), "Чижевський - фрундатор поняття "фрілософрія серця"'", Слово і Час, № 8. Київ, с. 83-89.

Игнатий Брянчанинов, (1989), "Слово о человеке", Богословские труды. Сборник, №29, МоСква, с. 284-320.

арх. Ианнуарий (Ивлев), (2001), "Основные антропологические понятия в посланиях Святого Апостола Павла", Альфра и Омега. Альманах, № 31, Москва, с. 13-18.

арх. Киприян (Керн), (1950), "Святоотеческое учение о человеке. Начало: Апостол Павел", Антропология свт. Григория Паламы, гл. 2. Париж, 505 с. Электронный ресурс. Режим доступа (25.06.2019): https://www.portal-slovo.ru/theology/37572.php?ELEMENT_ ID $=37572$

Коряков П. В., (2014), "Идея невидимой брани в богословии святого апостола Павла", Моло-

\footnotetext{
${ }^{20}$ Праксис (від давньогрецького тра́ Łı - діяльність, активність) - цілеспрямована духовнопрактична діяльність людини.
} 
дой ученый, №1 (60), Казань, с. 653-657.

Попова В. В., (2009), "Синтез науки и религии в философии В.Ф. Войно-Ясенецкого", Вестник Нижегородского университета им. Н.И. Лобачевского. Серия "Социальные науки", № 2 (14), с. 117-120.

Святитель Лука (Войно-Ясенецкий), (2009), Дух, душа, тело, Образ, Москва, 128 с.

Старец Паисий (Величковский), (1997), Крины сельные или цветы прекрасные. Учение стариа Паисия об Иисусовой Молитве, умом в сердие совершаемой. Товарищество "Задруга", Киев, 96 с.

Степанова И. Н. (2005), "Православная философия В.Ф. Войно-Ясенецкого", Весник ЮУрГУ, Серия "Социально-гуманитарные науки", №7 (47), с. 246-249.

Халезова Л. В. (2007), "Архиепископ Лука о сердце и его роли в формировании духовности", Культура народов Причерноморья, Симферополь, Вып. 118. с. 124-128.

Халезова Л. В. (2011), Життя та богословсько-проповідницька діяльність В. Войно-Ясенецького (архієпископа Луки) в контексті його філософрсько-релігійних поглядів, авторефрерат на здобуття наукового ступеня кандидата філософських наук, Інститут філософії імені Г. С. Сковороди Національної Академії наук України, Київ, 20 с.

Хоружий С. С. (1995), "Аналитический словарь исихастской антропологи", Синергия. Проблемы аскетики и мистики православия, ДИ-ДИК, Москва, с. 42-150.

\section{References}

Anokhin Konstantin, (2013), "The Codes of the Babylonian Library of the Brain" ["Kodb vavy'lonskoj by 'bly'oteky' mozga"], In the world of science. Special edition, pp. 83-89 [in Russian]

Valyavko I. (1998), "Chyzhevsky - founder of the concept of "philosophy of the heart"'" ["Chy'zhevs'ky'j - fundator ponyattya "filosofiya sercya"'"], Word and Time, No. 8. Kyiv, pp. 83-89 [in Ukrainian]

Ignatius Bryanchaninov, (1989), "A Word about Man" ["Slovo o cheloveke"], Theological works. The collection, №29, Moscow, pp.284-320 [in Russian]

arch. lannuari (Ivlev), (2001), "The main anthropological notions in the epistles of the Holy Apostle Paul" ["Osnovnyye antropologicheskiye ponyatiya v poslaniyakh Svyatogo Apostola Pavla"], Alpha and Omega. Almanac, No. 31, Moscow, pp. 13-18 [in Russian]

arch. Kipriyan (Kern), (1950), "Patristic teaching about man. Beginning: Apostle Paul" ["Svyatootecheskoye ucheniye o cheloveke. Nachalo: Apostol Pavel"], Anthropology of St. Gregory Palamas, chap. 2, viewed: 25 June 2019, available at: https://www.portal-slovo.ru/ theology/37572.php?ELEMENT_ID=37572 [in Russian]

Koryakov P. V., (2014), "The idea of invisible battle in the theology of the holy Apostle Paul" ["Ideya nevidimoy brani v bogoslovii svyatogo apostola Pavla"], Young Scientist, No. 1 (60), Kazan, pp. 653-657 [in Russian]

Popova V. V, (2009), "Synthesis of science and religion in the philosophy of V. F. Voyno-Yasenetsky" ["Sy'ntez nauky` y' rely'gy`y' v fy'losofy'y` V.F. Vojno-Yaseneczkogo"], Bulletin of Nizhny Novgorod University. N.I. Lobachevsky. Series "Social Sciences", No. 2 (14), pp. 117-120 [in Russian]

St. Luke (Voyno-Yasenetsky), (2009), Spirit, soul, body [Dukh, dusha, telo], Image, Moscow, 128 p. [in Russian]

St. Paisiy (Velichkovsky), (1997), Krills or elite flowers are beautiful. The doctrine of the St. Paisius about the Jesus Prayer, with the mind in the heart perpetrated [Kriny sel'nyye ili tsvety prekrasnyye. Ucheniye startsa Paisiya ob lisusovoy Molitve, umom v serdtse sovershayemoy], Partnership "Zadruga", Kiev, 96 p. [in Russian] 
Stepanova I. N. (2005), "Orthodox philosophy V. F. Voyno-Yasenetsky" ["Pravoslavnaya fy'losofy ya V. F. Vojno-Yaseneczkogo"], Vesnik of SUSU, Series "Social and Humanitarian Sciences", No. 7 (47), pp. 246-249 [in Russian]

Khalezova L. V. (2007), "Archbishop Luke about the heart and its role in the formation of spirituality", ["Arxy`epy`skop Luka o serdce y` ego roly` v formy`rovany`y` duxovnosty'"], Culture of the peoples of the Black Sea region, Simferopol, No. 118, pp. 124-128 [in Russian]

Khalezova L. V. (2011), Life and theological and preaching activities of V. Voyno-Yasenetsky (archbishop Luke) in the context of his philosophical and religious views] [Zhy'ttya ta bogoslovs 'ko-propovidny'cz'ka diyal'nist' V. Vojno-Yasenecz 'kogo (arxiyepy'skopa Luky') $v$ konteksti jogo filosofs 'ko-religijny'x poglyadiv,] Author's thesis, G. S. Skovoroda Institute of Philosophy of the National Academy of Sciences of Ukraine, Kiev. 20 p. [in Ukrainian]

Khoruzhy S. S. (1995), "Analytical Dictionary of Hesychast Anthropology" ["Analiticheskiy slovar' po isikhastskoy antropologii. Synergy"], Synergy. Problems of asceticism and mystic of Orthodoxy, DI-DIK, Moscow, pp. 42-150 [in Russian]

(c) Олена Борисівна Величко 